\title{
Assessment Instruments Development of Islamic Values in Experiment with Natural Pectin as a Corrosion Inhibitor
}

\author{
Cucu Zenab Subarkah, Asri Nuansa Qolbi \\ Department of Chemistry Education \\ UIN Sunan Gunung Djati \\ Bandung, Indonesia \\ zenabsc@uinsgd.ac.id, qolbiey.terence@gmail.com
}

\author{
Muhammad Minan Chusni \\ Department of Physics Education \\ UIN Sunan Gunung Djati \\ Bandung, Indonesia \\ minan.chusni@uinsgd.ac.id
}

\author{
Mahmud Mahmud \\ Department of Islamic Education \\ UIN Sunan Gunung Djati \\ Bandung, Indonesia \\ mahmud@uinsgd.ac.id
}

\begin{abstract}
Experimental activities should be complemented by an assessment instrument that requires learners in addition to scientific thinking can also develop values. This study aims to develop an assessment instrument of Islamic values on the experimental use of pektin from lemon peel as a corrosion inhibitor. The research method used is Research and Development (R\&D) which consists of define, design, develop and disseminate. The research instrument used includes questions of values related to corrosion and its prevention processes linked to the Zulkarnain story listed in the Al-Koran of Surat al-Kahf. The results of this study are in the form of an assessment instrument of feasible Islamic values and can be used in corrosion experiments.
\end{abstract}

Keywords-assessment; islamic values; pectin; corrosion inhibitor.

\section{INTRODUCTION}

In the present era, the idea of integrative science resonates in various concepts, such as the Islamization of science, the saintification of the Qur'an, and the objectification of the teachings of Islam. The whole concept is actually want of Islamic science is not just a medium of propaganda but in return to purity as a system of science that has the function of transformative and responsive to modern issues in line with the demands of society. To face these demands required Integration, Internalization, of Islamic Science known as 3I. 3I in the realm of science there are three models, namely: 1) integration model in the curriculum package; 2) the naming model of the course showing the relationship between two general and Islamic disciplines; 3) model of integration in the subject themes [1].

Integration and internalization of science is a must because according to [2], a superior civilization is built by all elements of the nation that has a strong character, positive, and resilient. In fact, education has put forward a lot of cognitive aspects, such as giving many tasks without touching tasks that can develop character values. The facts of the world of education and other social phenomena that arise among learners are the occurrence of student fights, drugs, free sex and cheating in various types of examinations. Even the thing that recently happened was the invitation of bikini bikini after UN 2015 SMA / equal. In addition to the cases of high school / equivalent students, based on research that has been done to the students Luthfiyah chemical education, there are characters of students who are less good during the learning process, such as dishonesty during practicum by falsifying observation data [3]. Some of the cases that have been mentioned are a matter of education that must be overcome, because the character of a strong nation, competitive and noble character is the ideals of national development.

The Quran contains the core ethical values that are described to be some of the value of the behavioral source. The value is the value of faith, honesty, responsibility, caring, discipline, courage and citizenship. The process of internalizing these core ethical values must be done through teaching, modeling, motivation, habituation and enforcement of rules to produce character behaviors in learners [2].

In relation to the process of internalizing character values on each subject, [4] states that the chemistry lessons contain the value of order that leads to God's glorification. If the chemical phenomenon is dug deeper and accompanied by the Quranic verses that explain it, it will get the values of Islam that can be used as the foundation of the development of the character of learners in learning.

One of the chemical concepts related to everyday life and contained in the Quran is the concept of electrochemistry and redox reactions. The Quran explains that Zulkarnain built a strong iron fort by means of coating iron with copper. Because of Zulkarnain's electrochemical principle, the destroyers of Yakujuj Makjuj could not destroy the built iron fortress. This can be an analogy that in order to avoid the destruction of the 
character of the nation's children, protection or prevention is needed, one of them by instilling and reinforcing Islamic values. The story in the Quran is something that can be integrated into chemistry subjects to internalize the value of characters in learning.

On the other hand, the concept of electrochemistry is a concept that requires the provision of a direct learning experience. Appropriate learning approach to support the process is experiment. The experimental method is a way of teaching, where the student performs an experiment on something, observes the process and writes the results of the experiment, then the results of the observation are submitted to the class and evaluated by the teacher [5].

Previous research that incorporated character values into chemistry subjects was [6] who examined the "Value-based Chemistry Learning Design on the Topics of Chemical Laws". Similar research has also been conducted on different material contexts, including research on chemical bonding, chemical role in life and nature of the periodicity of the elements. The results of some of these studies show that learning outcomes using a scientific approach and incorporating integrated chemical content content with value is good and is recommended for further development. There has been research on the internalization of Islamic values through a scientific approach to electrochemical learning without experimenting [7]. Furthermore, there has been developed an inquiry-based Worksheet in the experimental pectin utilization of lemon skin waste as a corrosion inhibitor.

The difference of this research is to develop Islamic values that come from the story in Quran, through experimental activity on the utilization of lemon skin pectin waste as corrosion inhibitor. In addition to the Worksheet for the experimental activities of the previous research also made a questionnaire to explore the attitudes of the Islamic student values. The Islamic values that are expected to arise from students in the learning process are honesty, fairness, beneficial to others, humble, efficient work, vision for the future, high discipline and balance [8].

Implementation of corrosion learning by using the media in the form of worksheets can help students can interconnect with quran as the basis for the development of Islamic values [9] [7]. During this time corrosion learning has not touched up to develop Islamic values. Learning resources are just a reference book that sometimes students are lazy to read it. The implementation of corrosion-related learning has been implemented without touching the development of Islamic values.

The use of worksheets can be combined with an attitude assessment so that students are active in answering questions about the experiment and at the same time measuring Islamic values. The statement of Islamic values is associated with corrosion events contained in the Qur'an as contained in the story of Zulkarnain in Surah Al-Kahfi's of quran. Through this research will be developed an appropriate assessment of Islamic values and can be used in natural pectin experiments as corrosion inhibitors.

\section{Methodology}

The method used in this research is the method of research and development (R\&D). R\&D method is a research method used to produce a specific product and test the effectiveness of the product [10]. Stages of this method are known as 4D, including: Define, Design, Develop, and Disseminate [11].

The subjects of the research are expert lecturers as product testers of questionnaire format of Islamic values attitudes made, and chemical education students who have taken the subject of Chemistry 2 as many as 42 people for the limited test.

The research instrument used in this study is a questionnaire aimed at validity and feasibility test on the product made.

\section{RESULTS AND DISCUSSION}

After collecting the data then obtained the results of research in the form of validation results of materials, construction and language / cultural instruments of the lecturers as much as 3 people and empirical validation of the test instrument to 42 respondents of students.

\section{A. Expert Validation Results}

Validation is done on the material, construction and language / cultural aspects with the details of the aspect as Table I. Validation is done by three experts namely construction and language experts, character education specialists and chemistry education experts with the following results.

TABLE I. RESULT OF VALIDATION QUESTIONNAIRE ATTITUDE OF ISLAMIC VALUES

\begin{tabular}{|c|c|c|c|c|c|}
\hline \multirow[b]{2}{*}{ Aspect } & \multicolumn{3}{|c|}{ Rating Result } & \multirow[b]{2}{*}{$\begin{array}{l}\text { Ave } \\
\text { rage }\end{array}$} & \multirow{2}{*}{$\begin{array}{c}\text { Categor } \\
\mathbf{y}\end{array}$} \\
\hline & $\begin{array}{c}\text { Validato } \\
r 1\end{array}$ & $\begin{array}{c}\text { Validator } \\
2\end{array}$ & $\begin{array}{c}\text { Validator } \\
3\end{array}$ & & \\
\hline Material & 88.3 & 84.4 & 80 & 84.3 & $\begin{array}{l}\text { Very } \\
\text { good }\end{array}$ \\
\hline Construction & 89.2 & 87.5 & 82.3 & 86.3 & $\begin{array}{l}\text { Very } \\
\text { good }\end{array}$ \\
\hline $\begin{array}{c}\text { Language / } \\
\text { Cultural }\end{array}$ & 88.9 & 90 & 85.6 & 88.2 & $\begin{array}{l}\text { Very } \\
\text { good }\end{array}$ \\
\hline
\end{tabular}

Based on the result of validation of the content of Islamic value assessment sheet to the material expert, konstrusksi, language / culture shows the result in the range 80-89. It shows that the instruments developed and mastered by the experts show the results in a decent category [12]. It means that the instrument of attitude is ready for use by students to measure the attitudes of Islamic values contained in the Quran Surah al-Kahf verses 83-98.

\section{B. Instrument Validation Proceeds}

An experimental test was conducted in order to know the empirical validity of each item of statement contained in the questionnaire instrument of Islamic values. The process is done by distributing questionnaires to 42 respondents who are students of chemistry education semester 3 class B who have obtained electrochemical materials and redox reactions in basic chemistry courses. The points of the statement of the questionnaire of Islamic values are divided into 12 statements consisting of several dimensions of Islam: honesty, fairness, usefulness to others, humble, efficient work, vision for the future, high discipline and balance described in some 10 
indicators in accordance with Islamic dimensions and material about corrosion.

After obtained the test results then analyzed by using statistics to determine the validity of each item by calculating the product moment correlation value [13]. Then from the correlation value is compared with the critical $r$ that is 0.3 . Minimum requirement to be eligible (valid) if $r=0.3$ or more; and when $r<0.3$ the item is not eligible (invalid) as it is involved in Table II.

\section{TABLE II. VALIDATION TEST RESULTS OF THE INSTRUMENT}

\begin{tabular}{|l|l|l|}
\hline No. & \multicolumn{1}{|c|}{$\boldsymbol{r}_{\text {count }}$} & Information \\
\hline 1 & 0.42 & valid \\
\hline 2 & 0.55 & valid \\
\hline 3 & 0.46 & valid \\
\hline 4 & 0.06 & invalid \\
\hline 5 & 0.36 & valid \\
\hline 6 & 0.46 & valid \\
\hline 7 & 0.34 & valid \\
\hline 8 & 0.69 & valid \\
\hline 9 & 0.60 & valid \\
\hline 10 & 0.56 & valid \\
\hline 11 & 0.40 & valid \\
\hline 12 & 0.48 & valid \\
\hline
\end{tabular}

Based on the results of empirical validation of the Islamic value assessment sheet to students through field trial. Then the data obtained from 12 statements of attitudes that developed there 1 item of invalid statements meet the criteria of product moment correlation [13]. Furthermore, the results obtained as many as 11 questions that are used as the instrument of the value of the data on the taking of the data in this research.

\section{Instrument Reliability Results}

Based on the product moment correlation equation, we can get the correlation on the instrument of attitude of the Islamic values, as shown in Table III.

\section{TABLE III. INSTRUMENT RELIABILITY TEST RESULTS}

\begin{tabular}{|c|c|c|}
\hline Variable & $\mathbf{r i i}_{\text {ii }}$ & Information \\
\hline The attitude of Islamic values & 0.6 & $\begin{array}{c}\text { Reliable in medium } \\
\text { category }\end{array}$ \\
\hline
\end{tabular}

In addition to testing the validity of intruments attitude of Islamic values, also tested the reliability to know the consistency of the instrument when used as a tool of data pengumpuan for different subjects. Berdasrakan reliability analysis results obtained by reliability value using Spearman Brown formula of 0.6 which means that the reliability of the instrument in the category of medium [10].

\section{Discussion}

In the process of taking this research data is done on different respondents with at the time of trial. The subjects of this study amounted to 40 students of chemical education semester 3 class A. Distribution of questionnaires attitudes of Islamic values can be seen in Table IV.
TABLE IV. RESULT QUESTIONNAIRE ATTITUDE OF ISLAMIC VALUES

\begin{tabular}{|c|c|c|c|c|c|}
\hline \multirow{2}{*}{ No } & \multirow{2}{*}{ Statement } & \multicolumn{4}{|c|}{ Response } \\
\hline & & $S S$ & $S$ & $T S$ & STS \\
\hline 1 & $\begin{array}{l}\text { Underground oil channel builders } \\
\text { should select the pipeline material at } \\
\text { the lowest possible cost in order to } \\
\text { minimize costs. }\end{array}$ & 5 & 27 & 3 & 5 \\
\hline 2 & $\begin{array}{l}\text { Corrosion is a natural phenomenon } \\
\text { that involves the electrochemical } \\
\text { process and is a manifestation of the } \\
\text { greatness and power of God. }\end{array}$ & 30 & 10 & 0 & 0 \\
\hline 3 & $\begin{array}{l}\text { As the times progressed, scientific } \\
\text { and technological sciences } \\
\text { developed to solve various problems } \\
\text { in various fields. This shows only } \\
\text { the greatness of man in mastering } \\
\text { various disciplines. }\end{array}$ & 20 & 17 & 2 & 1 \\
\hline 4 & $\begin{array}{l}\text { One of the corrosion inhibitors can } \\
\text { be made from lemon leather waste } \\
\text { material. This shows the greatness of } \\
\text { God. }\end{array}$ & 29 & 10 & 0 & 0 \\
\hline 5 & $\begin{array}{l}\text { As a matter of concern for the } \\
\text { environment, iron fences should be } \\
\text { painted periodically to avoid the } \\
\text { formation of rust that can endanger } \\
\text { health. }\end{array}$ & 11 & 28 & 0 & 1 \\
\hline 6 & $\begin{array}{l}\text { The construction of petroleum } \\
\text { pipelines should consider the } \\
\text { impacts that may arise in the event of } \\
\text { a leak, so a precaution should be } \\
\text { taken, although additional costs may } \\
\text { be required. }\end{array}$ & 28 & 11 & 1 & 0 \\
\hline 7 & $\begin{array}{l}\text { The Qur'an is the holy book of the } \\
\text { Islamic ummah in which it contains } \\
\text { only the arguments relating to } \\
\text { human life but is less relevant to } \\
\text { modern science. }\end{array}$ & 27 & 11 & 2 & 0 \\
\hline 8 & $\begin{array}{l}\text { Iron is a strong material but it can } \\
\text { turn to rust. Neither with humans, as } \\
\text { strong and powerful as any will age. } \\
\text { Therefore before we grow old we } \\
\text { should feel great. }\end{array}$ & 25 & 13 & 0 & 2 \\
\hline 9 & $\begin{array}{l}\text { Zulkarnain protects the weak from } \\
\text { the raids and forces by exploiting the } \\
\text { intelligence he possesses. Today we } \\
\text { can harness the power and } \\
\text { intelligence we have to gain power } \\
\text { in the defense of the weak. }\end{array}$ & 9 & 30 & 1 & 0 \\
\hline 10 & $\begin{array}{l}\text { Yakjuj and Makjuj as physical and } \\
\text { moral destroyers in modern times is } \\
\text { more powerful than the Zulkarnain } \\
\text { era. Therefore we constantly } \\
\text { increase faith and piety to God. }\end{array}$ & 33 & 6 & 1 & 0 \\
\hline 11 & $\begin{array}{l}\text { The skin of fruits as waste can be } \\
\text { processed as pectin to prevent } \\
\text { corrosion. This is proof that God is } \\
\text { affectionate. }\end{array}$ & 23 & 17 & 0 & 0 \\
\hline
\end{tabular}

In more detail the distribution of the response result of the attitude of the students' Islamic values in the SS category = strongly agree, $\mathrm{S}=$ agree, $\mathrm{TS}=$ disagree and STS = strongly disagree.

At the statement 1st, student asked his opinion to determine the decision in the builder of the underground oil channel should be selected pipe material with the lowest cost possible in order to minimize the cost. as many as 32 students responded 
positively while 8 students responded negatively. In order to make the pipeline of oil durable and safe it is necessary that cost in accordance with the standard. From these results, most students still think that working efficiency is identical with low cost, it should be understood that efficient means to have a more durable and safe. This is in line with the results of research about the ability of students in selecting material on making technology works that the student has a consideration that is in line with the criteria of material selection according to the science of materials. Consideration in material selection including strength, use, workmanship, availability, and pricing. The main criterion in material selection is based on the calculation of force and stress experienced by the component during work [14].

The result of the 2 nd statement is expected to have an Islamic attitude in understanding the balance of nature, with the result entirely stated positively and realizing that corrosion is a natural phenomenon involving electrochemical process and is a manifestation of the greatness and power of God. This is in line with Novianti's opinion that we have a great responsibility to maintain the balance of nature and environment for the welfare of human life on this earth [15].

The result on the 3rd statement is expected to have high disciplinary attitude in every activity. As indicated in terms of resolving problems in various fields. A total of 37 students argue that they are able to solve every problem solely with the trap they have, while the other 3 states not so. This is in line with the opinions of Stein and Book that there are four aspects in solving the problem that is: being cautious, self-discipline, systematic in dealing with and looking at problems and not avoiding the problem [16].

In the 4th statement, it is hoped that students realize God's justice about all things created must have benefits. Seen from the opinions of all-glorious responding positively to the statement One of the corrosion inhibitors can be made from the waste material of lemon skin. It shows the greatness of God. This is in accordance with the opinion that in Islam's view, nature is an entity which is not independent, but relates to human beings and to other interconnected, related and mutual realities which give rise to a harmonious and equitable relationship, greatness of God [17].

The result of statement 5th, 39 students stated positive response to pay attention to the environment by painting fence made of iron so as not to appear damage in the form of corrosion. It shows that students are able to be fair to their belongings to care for and guard against damage. This is in accordance with the Qur'anic Surah Al-Anbiya verses 107, Allah Almighty says: And we have not sent you, but to be a mercy to the worlds. Rahmatan lil alamin is not just the motto of Islam, but is the goal of Islam itself. In accordance with that purpose, it is only natural that Islam pioneered the management of nature and the environment as a manifestation of compassion for the universe. In addition to prohibiting the destruction of the earth, Islam also has an obligation to protect the environment and respect the universe which includes the universe in which it includes humans, plants, animals, other living things, and non-living beings such as iron [18].
In the 6th statement students are expected to be able to think forward / visionary in everyday life. Ha emerged with a statement of positive attitudes as many as 39 students of them supported to use quality materials to prevent pipeline leakage although expensive. This is in line with Tiwan's research results to prioritize the selection of appropriate materials [14].

The result of the attitude of the students that is expected to appear in the 7th statement is honesty to acknowledge that the Qur'an is the holy book of the Islamic ummah in which it is relevant to the human life of both science and technology of the future. As a great student, we do not yet understand that the content of the quran is closely related to modern science with as many as 38 students expressing positive attitudes toward the process. Yet as written in the study of "The role of science in the knowledge of God" that the search for Muslim scientists against natural phenomena due to the fact that they consider this science problem is one of the best ways to get closer to God. They are convinced that by studying God's signatures in this realm, one will be able to expose the interconnectedness of all parts of the universe and the unity hidden behind this diverse world, which in turn will guide the Creator [19].

From the 8th statement, students are expected to have a humble attitude that is reflected in every behavior. But most of the students as much as 38 people still feel great because given the advantages, whereas with the existing advantages we should to take advantage of the good and be humble [19]. As Mawardi reveals that human beings are permitted to exploit the potential available to survive and to continue their lives and for the common good, it should not be excessive, harmful to others and corrupt on the face of the earth [17].

The 9th statement contains the content of al-Kahf's letter about the story of Zulkarnain who has the power and strength to protect the weak. From the results of the assessment, 39 students stated positive, which means that they will apply the attitude of justice with the advantages and positions that they have for the common good [17].

Based on the 10th statement, students as many as 39 people are very supportive to high discipline in improving faith in God, as a provision to face the modern era and social decadence morale [20]. This is in line with the study of the relationship between religiosity and morality in adolescents in Madrasah Aliyah that the relationship is very significant between the two [21].

In the 11th statement, the expected attitudes arising from the students are efficient by utilizing the lemon waste skin as a corrosion inhibitor. A total of 40 students are supportive towards it. This is in line with the word of God in Surah Abasa verses 24-32 that Allah created these plants is for the benefit of humans and other living beings, of course, to be used in order to be useful for the needs of his life [22].

Furthermore, to see the percentage of respondents' responses to statements of Islamic values can be categorized into positive responses and negative responses. Positive response if students choose SS and S, while a negative response when choosing TS and STS. The distribution of Islamic values emerging from students after learning can be seen in Table V. 
TABLE V. OUTCOME OF ISLAMIC VALUES

\begin{tabular}{|c|c|c|c|}
\hline $\begin{array}{c}\text { Stete } \\
\text { ment }\end{array}$ & Islamic Values & Respon $(\boldsymbol{\%})$ & Category \\
\hline 1 & Work efficiently & 55.0 & Less \\
\hline 2 & Harmony & 93.8 & Good \\
\hline 3 & Discipline & 40.0 & Less \\
\hline 4 & Fairness & 91.3 & Good \\
\hline 5 & Fairness & 80.6 & Good \\
\hline 6 & Visionary & 91.9 & Good \\
\hline 7 & Honesty & 34.4 & Less \\
\hline 8 & Humble & 36.9 & Less \\
\hline 9 & Fairness & 80.0 & Good \\
\hline 10 & Discipline & 95.0 & Good \\
\hline 11 & Efficient & 89.4 & Good \\
\hline
\end{tabular}

In more detail the disclosure of the values of Islamic student values is shown in table $\mathrm{V}$. Negative statements are represented by numbers $1,3,7$ and 8 while positive positions are represented by numbers $2,4,5,6,9,10$ and 11 . Criteria for attitudes according to the percentage value of student response $(25-50)$ means less, (51-75) is sufficient and (76-100) is good [13].

Based on table $\mathrm{V}$ shows that chemical education students semeseter 3 class B has had the attitude of Islamic values in the good category for attitudes in statements 2, 4, 5, 6, 9, 10 and 11 while the less category for attitudes in statements $1,3,7$ and 8 of the Qur'anic content of the letter of al-Kahf ayati 83-98 on the story of Zulkarnain confront the Yakujuj-Makjuj applied in the event of corrosion of iron in daily life.

\section{CONCLUSION}

Based on the results of the discussion can be drawn keismpulan of this research are (1) The result of instrument validation based on Islamic values on the experiment of pectin of lemon skin waste as corrosion inhibitor according to the expert in material, construct and language aspects is valid and feasible, and (2) The result of the test of the instrument based on Islamic values on the experiment of pectin of lemon skin waste as corrosion inhibitor shows the Islamic values in very good category.

\section{ACKNOWLEDGMENT}

This research activity is supported by LP2M, UIN Sunan Gunung Djati Bandung through Competitive Grant: Cross-Prodi Collaborative Research using DIPA UIN Sunan Gunung Djati Fiscal Year 2017.

\section{REFERENCES}

[1] M. A. Abdulloh, Islamic Studies Dalam Paradigma IntegrasiInterkoneksi (Sebuah Antologi). Yogyakarta: Suka Press, 2007.

[2] A. Hasanah, Pendidikan Karakter Berpersfektif Islam. Bandung: Insan Komunika, 2013.
[3] H. Luthfiyah, "Pengembangan Keterampilan Berpikir Kritis Mahasiswa melalui Praktikum Titrasi Reduksi Oksidasi Berbasis Diagram Alir pada Mata Kuliah Kimia Analaitik II," UIN Sunan Gunung Djati, Bandung, Skripsi 2014.

[4] A. Nugroho, "Biologi, Sains, Lingkungan, dan Pembelajarannya Menuju Pembangunan Karakter," in Seminar Nasional VIII Pendidikan Biologi, Surakarta, 2008, p. 304.

[5] S. Sagala, Konsep dan Makna Pembelajaran : Untuk Membantu Memecahkan Problematika Belajar dan Mengajar. Bandung: CV. Alfabeta, 2005.

[6] S. P. Marpu'ah, "Desain Pembelajaran Kimia Bermuatan Nilai Pada Subtopik Sifat-Sifat Keperiodikan Unsur," UPI, Bandung, Skripsi 2014.

[7] C. Z. Subarkah, R. Rahmawati, and A. Dalli, "Internalizing Islamic Values in Electrochemistry Learning," Jurnal Pendidikan Islam, vol. 2, no. 2, pp. 270-286, 2016.

[8] A. G. Agustin, Rahasia Sukses Membangkitkan ESQ power : Sebuah Inner Journey Melalui Ihsan. Jakarta: ARGA, 2003.

[9] A.N. Maryati, Y. Sunarya, and Kurnia, "Lembar Kerja Siswa (LKS) Eksperimen Dan Non Eksperimen Berbasis Inkuiri Terstruktur Yang Dikembangkan Pada Subpokok Materi Pergeseran Kesetimbangan Kimia," in Simposium Nasional Inovasi Dan Pembelajaran Sains, Bandung, 2015, p. 181.

[10] Sugiyono, Metode Penelitian Kualitatif dan $R$ \& D. Bandung: CV ALfabeta, 2009.

[11] S. Haryati, "Research and Development (R\&D) Sebagai Salah Satu Model Penelitian dalam Bidang Pendidikan," vol. 37, no. 1, pp. 11-26, 2012.

[12] N. Sudjana, Dasar- Dasar Proses Belajar Mengajar. Bandung: Sinar Baru Algesindo, 2009.

[13] S. Arikunto, Prosedur Penelitian Suatu Pendekatan Praktik. Bandung: Rineka Cipta, 2010.

[14] Tiwan, "Kemampuan Mahasiswa dalam Memilih Material Pada Pembuatan Karya Teknologi," Jurnal Pendidikan Teknologi dan Kejuruan, vol. 22, no. 1, pp. 99-107, 2014.

[15] M. Novianti, "Peran Pendidikan Islam dalam Pelestarian," Journal of Empirical Research in Islamic Education, vol. 2, no. 2, pp. 129-151, 2014.

[16] Stein and Book, Ledakan IQ: 15 Prinsip Dasar Kecerdasan Emosional Meraih Sukses. Bandung: Kaifa, 2002.

[17] M. Mawardi, "Air dan Masa Depan Kehidupan," Jurnal TARJIH, vol. 12, no. 1,2014

[18] L. J. Fua, "Aktualisasi Pendidikan Islam dalam Pengelolaan Lingkungan Hidup Menuju Kesalehan Ekologis," Jurnal Al-Ta'adib, vol. 7, no. 1, pp. 19-36, 2014.

[19] L. Jidi, "Peranan Sains dalam Mengenal Tuhan," Jurnal Dakwah Tabligh, vol. 14, no. 2, pp. 217-226, 2013.

[20] F. Affandi and M. Masudi, "Studi Tentang Korelasi dan Moral," $A L$ Hikmah : Jurnal Studi Agama-Agama, vol. 3, no. 2, 2017.

[21] I. F. REza, "Hubungan antara Religiusitas dengan Moralitas pada Remaja di Madrasah Aliyah," Humanitas, vol. X, no. 2, pp. 45-58, 2013.

[22] Efendi, "Perlindungan Sumber Daya Alam dalam Islam," Kanun Jurnal Ilmu Hukum, vol. 13, no. 55, pp. 17-31, 2011. 